\begin{tabular}{|l|c|c|c|r|}
\hline $\begin{array}{l}\text { Cuadernos de Investigación Geográfica } \\
\text { Geographical Research Letters }\end{array}$ & 2018 & N $^{\circ} 44(1)$ & pp. 245-265 & $\begin{array}{r}\text { ISSN 0211-6820 } \\
\text { eISSN 1697-9540 }\end{array}$ \\
\hline
\end{tabular}

\title{
A REVIEW OF THE LITTLE ICE AGE IN ANDALUSIA (SOUTHERN SPAIN): RESULTS AND RESEARCH CHALLENGES
}

F.S. RODRIGO

\author{
Dep. Chemistry and Physics, Centro Andaluz para el Estudio y \\ Seguimiento del Cambio Global (CAESCG), University of Almería, Spain.
}

\begin{abstract}
Andalusia (southern Spain) is a region of special climatic interest due to its geographical location, hydrological and orographical characteristics. In this work a summary of different approaches to study the Little Ice Age in this region is presented. From different proxy data (lake and marine sediments, geomorphological evidences, tree-rings, documentary data), it is possible to obtain the main characteristics of this climatic episode, with predominance of colder and wetter conditions than today and great variability. However, some uncertainties persist, related to the chronological limits of the LIA in the region, the variability of thermal and rainfall conditions, and different time resolution of various proxy data analysed. These problems are discussed and future research challenges are proposed.
\end{abstract}

Una revisión sobre la Pequeña Edad del Hielo en Andalucía (sur de España): resultados y retos de investigación

RESUMEN. Andalucía (sur de España) es una región de especial interés climático debido a su posición geográfica y sus características hidrológicas y orográficas. En este trabajo se presenta un resumen de las diferentes aproximaciones al estudio de la Pequeña Edad de Hielo en esta región. A partir de diferentes datos proxy (sedimentos lacustres y marinos, datos geomorfológicos, anillos de árboles, datos documentales) es posible inferir las principales características de este episodio climático, con predominio de condiciones más frías y húmedas que hoy y una gran variabilidad. Sin embargo, persisten algunas incertidumbres, relacionadas con los límites cronológicos de la Pequeña Edad de Hielo, la variabilidad de las condiciones térmicas y pluviométricas, y la diferente resolución temporal de los distintos datos proxy analizados. Se discuten estos problemas y se proponen futuras vías de investigación.

Key words: Little Ice Age, climate variability, Andalusia, proxy data.

Palabras clave: Pequeña Edad del Hielo, variabilidad climática,Andalucía, datos proxy.

Received: 26 April 2017 Accepted: 26 July 2017

Corresponding author: F.S. Rodrigo, Dept. Chemistry and Physics, Centro Andaluz para el Estudio y Seguimiento del Cambio Global (CAESCG), University of Almería, Spain. E-mail address: frodrigo@ual.es 


\section{Introduction}

The Little Ice Age (LIA) is the last cold climatic period on a planetary scale prior to the current global warming. The duration and intensity of this cold event varied among different geographical areas although normally it is considered that the LIA comprises the period between the fourteenth and nineteenth centuries (Jones and Bradley, 1992; Mann, 2002; Le Roy Ladurie, 2004). The LIA provides a good opportunity of investigating the possible natural mechanisms affecting climate on decade to century time scales.

Andalusia (southern Spain) is an interesting region for climatic studies due to its geographical and latitudinal position, around $37^{\circ} \mathrm{N}$, influenced by the flows from the Atlantic Ocean and the Mediterranean Sea. Sierra Nevada forms part of the Betique Range and contains the highest peaks in Western Europe outside the Alps (Mulhacén $3478 \mathrm{~m}$ above sea level (a.s.l.), and Veleta, $3398 \mathrm{~m}$ a.s.l.). Therefore this region presents a sharp altitudinal gradient in a relatively small area (Fig.1). The influence of the Atlantic Ocean and the Mediterranean Sea, together with the orographic characteristics of the region, allow to distinguish between river basins draining towards the Atlantic (mainly the Guadalquivir River) and those to the Mediterranean. The rainfall regime in the western area is mainly governed by Atlantic fluxes, with a clear influence of the North Atlantic Oscillation (NAO), especially in winter (Luterbacher et al., 2002; Trigo et al., 2004). The Mediterranean eastern area is sheltered from Atlantic disturbances because of the presence of rough reliefs flanking the coast, and it is affected by torrential, convective rains, which occur mainly in autumn (Sumner et al., 2001). The main disturbances of the Andalusian climate are linked to the jetstream behaviour and the polar front, that is, Andalusia is exposed to the typical influences of the planetary temperate zone of middle latitudes, although northern Africa subtropical influences also must be taken into account (Martín-Vide, 2007). On the other hand, this region has a long history of human activities, such as the intensification of the agriculture or land use changes altering fluvial activity (Benito et al., 2008). The Mediterranean Basin, and in particular Andalusia, located to the west of this area, has been recognized as one of the hot-spots of climatic change (Giorgi, 2006). Therefore, the study of this region during the LIA is of great interest.

The relative wealth of paleoclimatic data with high temporal resolution allows to study the LIA in Andalusia and obtain an overview of the climatic conditions in the region during this period. Even so, each method of paleoclimatic reconstruction has strengths and limitations, and we must be cautious in interpreting its results. Here a summary of studies focused on the Little Ice Age in southern Iberian Peninsula and based on different proxy data is presented. These studies are based on geomorphic evidences, lake sediments, paleofloods, tree-rings, documentary data and early instrumental data. Figure 1 shows the spatial location of different proxy data commented in the text: Sierra Nevada mountains (geomorphological and lake sediments), Cazorla and Filabres mountains (tree-rings), Guadalquivir River, Vera River, and Guadalentín River (paleofloods), Doñana, in the mouth of the Guadalquivir River (sediments, tree-rings, geomorphological, documentary data), Zoñar lake and Alborán Sea (sediments), as well as different cities in the region (Cádiz, Sevilla, Málaga, Jaén, Granada) with documentary and early instrumental data. This work does not pretend to be a complete and comprehensive review of all the published works, but an introduction to paleoclimatic reconstructions of the LIA in Andalusia. 


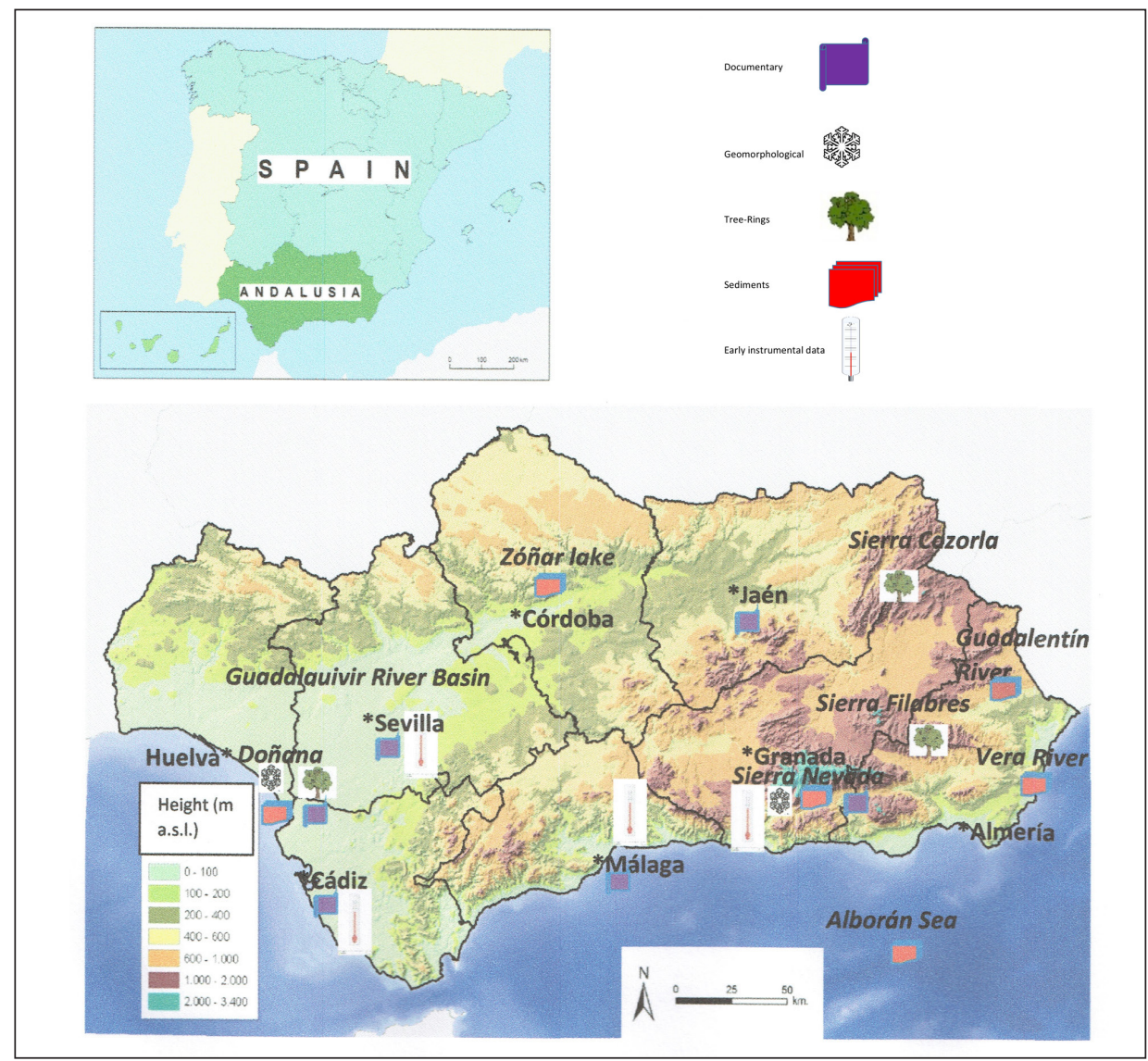

Figure 1. Map of Andalusia, indicating height above sea level. Main cities are indicated, as well as location of main proxy data in the region.

\section{Evidences from proxy data}

\subsection{Geomorphological processes in Sierra Nevada}

The existence of colder climate conditions during the LIA in southern Spain is apparent in the high mountain area of Sierra Nevada (Schulte, 2002). For the peaks of the Sierra Nevada there is abundant sedimentological and contemporary documentary evidence that reflects a historical period characterized by active geomorphological processes linked to colder temperatures between the 14th and 19th centuries (Oliva et al., 2014). A small glacier developed during the LIA in the cirque Corral del Veleta (Gómez-Ortiz et al., 2012). In spite of the difficulty in establishing precise chronologies (Oliva et al., 2011), the chronology deriving from La Mosca lake record reveals the existence of a glacial area in the Mulhacén cirque between the middle of the 15th century and the beginning of the 18th (Oliva and Gómez-Ortiz, 
2012). Geomorphological studies allow us to analyse the extension of the moraines, with the maximum dated at the first half of the 17 th century, minor advance from the end of the 19th century, and deglaciation and continuous and accelerated retreat in the first decades of the 20th century (González-Trueba et al., 2008). There are no glaciers today in the Sierra Nevada. During the mid-20th century the last glaciers melted, resulting in the complete deglaciation of the massif (Gómez-Ortiz et al., 2012a). At present there is only one rock glacier in the Sierra Nevada, which results from the degradation of a previous glacier (Gómez-Ortiz et al., 2012b).

Periglacial slope processes inferred from solifluction landforms, geomorphic activity from La Mosca lake sediments and historical documents suggest that climate conditions were more humid and colder than current ones, favourable to maintaining a relatively high number of summer snow patches in the Sierra Nevada and possible isolated appearances of glacial events (Oliva and Gómez-Ortiz, 2012). Samples of pollen analysis from the peat bog in Borreguil de la Caldera allowed the detection of increases in Pinus forest with ca. 30-yr resolution, which indicates wetter climatic conditions during the LIA at ca. 1300, 1410, 1550-1620 and around 1810 (Ramos-Román et al., 2016). Historical texts and sedimentological records provide evidence of the prevailing colder conditions in the massif, quantified at $0.9^{\circ} \mathrm{C}$ lower than present-day values (Oliva et al., 2016). Since the final decades of the 19th century, a trend towards warming is reflected in the geomorphological processes that take place in the Sierra Nevada (Oliva et al., 2014).

\subsection{Lake and marine sediments}

A direct relationship between rainfall and lake level has been documented during the last decades in Zoñar Lake ( $\left.37^{\circ} 29^{\prime} \mathrm{N}, 4^{\circ} 41^{\prime} \mathrm{W}\right)$, located in the Guadalquivir River Basin, close to Córdoba. Paleolimnological indicators, sedimentological and biological proxies, provide a detailed characterization in lake and watershed processes during the last 4000 years with a time resolution in the order of 30 years (Martín-Puertas et al., 2008, 2011). From these proxies, LIA seems to be characterized by a relatively more humid period (17th-18th centuries) and a relatively more arid period, but with high climatic variability during the 19th century (Martín-Puertas et al., 2008). Nevertheless, the geochemical signatures of the LIA are complex and unclear because of the occurrence of several arid and humid phases and intense human impact (intensification of agriculture) in the watershed since medieval times (Valero-Garcés et al., 2006; Martín-Puertas et al., 2011).

Marine records from the Alborán Sea have been revealed as excellent natural archives of paleoclimate and paleoceanographic reconstructions during the late Holocene (Nieto-Moreno et al., 2013). A high-resolution multiproxy approach from two deep-sea marine records from the Alborán Sea indicates that the LIA is characterized as a period of dry-humid phase alternation, with drier conditions at AD 1500-1600 and 1650-1750 and wetter conditions at AD 1600-1650 and 1750-1800 (Nieto-Moreno et al., 2013).

In summary, the LIA is characterized in both Alborán Sea and Zoñar records by an alternation of dry and humid periods, which indicates that climatic conditions seem to have been highly variable (Martín-Puertas et al., 2010). 


\subsection{Paleofloods}

Sedimentary sequences of fluvial records may provide high-resolution records occurring over short time periods (hour to days), mostly related to extreme hydrological events, in spite of the errors inherent in the dating methods (Thorndycraft and Benito, 2006). Dry (wet) conditions might have led to reduced (higher) flooding and discharge in the river catchments (Fletcher and Zielhofer, 2013). In the analysis of sediment records it is necessary to take into account human environmental modifications, especially since the 15 th century when bank protection structures, bridges and water mills were built (Uribelarrea and Benito, 2008).

Sediment records of paleofloods covering the last millennium indicate an abnormally high frequency of large floods in the Guadalquivir River basin near Córdoba in the periods AD 1590-1650, AD 1775-1810, and AD 1850-1890 (Uribelarrea and Benito, 2008). Similar periods of severe flooding (AD 1648-1672, AD 1769-1802, AD 1877-1900) have been found in the Guadalentín River situated to southeast Iberian Peninsula, between Almería and Murcia (Benito et al., 2010). Stratigraphic records of the lower Guadalete River (near Cádiz) reveal the intensification of fluvial dynamics during the LIA, with higher precipitation variability causing heavy run-off and increased soil erosion as well as floodplain sedimentation around AD 1600 (Wolf et al., 2014). During the LIA, river dynamics in the Vera basin (Almería province) was also very active, indicating high rainfall intensity at the end of the 16th and 18th centuries and during mid-19th century (Schulte, 2002).

\subsection{Tree rings}

Tree ring growth is limited, either directly or indirectly, by some climate elements, and these limitations can be quantified. Many studies have described the use of treering or dendroclimatic data to reconstruct past variations in climate variables (Creus, 2000). A study of the isotopic composition of carbon $\left({ }^{13} \mathrm{C} /{ }^{12} \mathrm{C}\right)$ in tree-rings of two species of pine (Pinus pinea, Pinus pinaster) from the National Park of Doñana (Huelva province), has been performed with the objective of validating its potential in the reconstruction of changing climate conditions and paleohydrological in the Southern Iberian Peninsula and of evaluating the effects of Global Change on the stress conditions of this ecosystem (Granados-Paéz, 2011). According to this study, the LIA in Andalusia may be characterised by an increase of rainfall and mild summer temperatures.

Creus and Puigdefábregas (1983) generated a chronology of 782 years of Pinus nigra Arnold subsp salzmanni from the Cazorla mountain range (Jaén province). According to this study, tree ring growth at these species is related to spring and summer temperature, and autumn and spring rainfall. This chronology was completed in the paper by Creus and Saz (2005), including chronologies from Sierra María and Sierra de Filabres (Almería province), and Sierra de Alcaraz (Albacete province). In this paper spring and summer precipitations since the 16th century are reconstructed. Results identified an alternation of dry periods (1598-1650, 1671-1687, and 1764-1781) and humid (1651-1670, and 1688-1739) of different duration and intensity. Manrique and Fernández-Cancio (2000), 
investigated the frequency of extreme values in 27 points distributed throughout Spain, finding that the most anomalous period occurred during the 16th and 17th centuries, coinciding with the coldest moment of the LIA. This high climate variability of the 16th and 17 th centuries has also been found in dendroclimatological studies covering the whole Mediterranean Basin (Nicault et al., 2008).

\subsection{Documentary data}

Documentary evidence provides information about past climate variability by means of direct or indirect descriptions of climate-related phenomena (Brázdil et al., 2005). Descriptive documentary data include weather observations, reports from chronicles, daily weather reports, travel diaries, ship logbooks, etc. In addition there is more indirect evidence that reflects weather events or climatic conditions such as the beginning of agricultural activities, rogations in favour or ending meteorological stress, data on agricultural productivity, etc.

In a first approach, historical documents are useful to complete and/or confirm the results of other proxy data. So, for instance, romantics, naturalists and scientists describe the Sierra Nevada's landscape since the 12th century, indicating the existence of glaciers in Sierra Nevada during the LIA. The historical sources document very small glaciers, only a few hundred meters long, at the base of the cirques and protected by high headwalls (Gómez-Ortiz et al., 2012; Oliva and Gómez-Ortiz, 2012). The combination of palaeoflood and historical records for obtaining data on floods that occurred during the last thousand years reduces the uncertainties associated with radiocarbon dating $(\sim 50$ years), and has even allowed the identification of individual events in the sedimentary record (Benito et al., 2008; Machado et al., 2011). Other example comes from the study of changes of the peat bog areas (Sousa et al., 2013) and coastal brooks (Sousa et al., 2015) in the Doñana Natural Park (Huelva province), which were investigated combining geomorphological tools with historical documents (chronicles, maps) from the 18th and 19th centuries. The results of these studies highlight that, from the beginning of the 17 th century to the end of the 20th, the extent of the peat bog areas has been gradually reduced, dating the end of the Lia in Andalusia at the end of the 19th century.

In general, descriptive evidence has a good dating control and high temporal resolution. However, descriptive evidence is discontinuous and biased by the subjectivity of the observer. Therefore, it is necessary to check the historical validity of documents before using them for climatic reconstructions. An overview on the documentary data sources in Andalusia, and the methodology used to analyse them, may be found in Rodrigo (2007). Alberola Romá (2014) provides a complete review on the LIA in Spain based on documentary data.

Precipitation patterns, due to their influence on agricultural yields, infrastructures and human activities, are the main climate variables reconstructed. Rodrigo et al. (1999, 2000) reconstructed a 500 year annual precipitation record for Andalusia (seasonal rainfall of Seville is reconstructed in Rodrigo and Barriendos, 2008). Results indicate alternating dry and wet phases: 1501-1589 dry, 1590-1649 wet, 1650-1775 dry, 1776- 
1937 wet, and 1938-1997 dry. Reconstruction of temperature values is more difficult, due to the absence of explicit information on this variable, but it was possible to obtain an estimate of the mean winter temperature in the Guadalquivir River Basin during the brief period $\mathrm{AD} 1780-1830$, finding that temperatures were up to $0.5^{\circ} \mathrm{C}$ lower than the modern 1960-1990 value (Rodrigo et al., 2012).

\subsection{Early Instrumental Data}

Instrumental observations (prior to the set-up of continuous meteorological networks) were taken since the late decades of the 18th century, at the peak of enlightenment, by initiatives linked to trans-oceanic navigation, agricultural production, and medical activities (Anduaga Egaña, 2012). In Andalusia, for the period 1780-1850, instrumental records corresponding to Sevilla, Cádiz, Málaga, and Granada have been found. In general terms, it is a set of scattered meteorological series, with short periods of observation, fragmented and with no homogeneous characteristics: each observer had different instruments and working procedures with no continuity in time (DomínguezCastro et al., 2014). Nevertheless these series may be useful to describe brief and extreme periods as, for instance, the frequent floods of the Guadalquivir River basin in the 1780s decade (Sánchez Rodrigo, 2016), or the so-called 'year without summer' 1816 (Trigo et al., 2009). The analysis of early instrumental data in the region is a work in progress.

\subsection{Climate model simulations}

Regional climate models are able to simulate a physically consistent climate, which is especially interesting in variables whose interaction with the topography is more important, such as precipitation (Gómez-Navarro et al., 2011). Even if the evolution of the simulation does not perfectly match the real evolution of the climate in the past, it represents a feasible evolution of the climate. Therefore, the simulated climate can be used to test some aspect of the reconstructions, such as variability of the series, physical relationships between variables, or methodological procedures (Rodrigo et al., 2012). This kind of questions can hardly be addressed within an atmosphere-ocean general circulation model. Therefore, simulations obtained from regional climate models may be a useful tool to examine the climate of historical periods.

Simulations of the past millennium climate in Spain were performed with the mesoscale model MM5 driven by the global model ECHO-G. For a full description of the capabilities of this model to reproduce a realistic climate over the Iberian Peninsula, the reader is referred to Gómez-Navarro et al. $(2011,2012)$. In the model, three independent sources of external forcings are considered: greenhouse gases, total solar irradiance, and global mean radiative forcing of volcanic aerosol (Crowley, 2000). Figure 2 shows the output of the model simulations of annual mean temperature (top) and cumulated rainfall (bottom) in Sevilla since AD 1501. 11 year moving averages (thick line in the graphs) were calculated to obtain a clearer overview of the results. In relation to temperatures, in a first approach three periods can be distinguished: 1501-1735 (mean temperature $\left.=13.8^{\circ} \mathrm{C}\right), 1736-1890\left(14.0^{\circ} \mathrm{C}\right)$, and $1891-1990\left(14.4^{\circ} \mathrm{C}\right)$. The main phase of the LIA would correspond to the first one, with mean temperature $0.6^{\circ} \mathrm{C}$ lower than the 20 th 
century mean. From middle 18 th century to the end of the 19 th century there was a slight recovering, but with mean temperature still $0.4^{\circ} \mathrm{C}$ lower than the modern mean value. The third period corresponds to the 20th century warming. For rainfall the simulation provides a fluctuating behavior, with alternating wet and dry periods, but since mid-19th century it is observed a progressive decrease of rainfall.

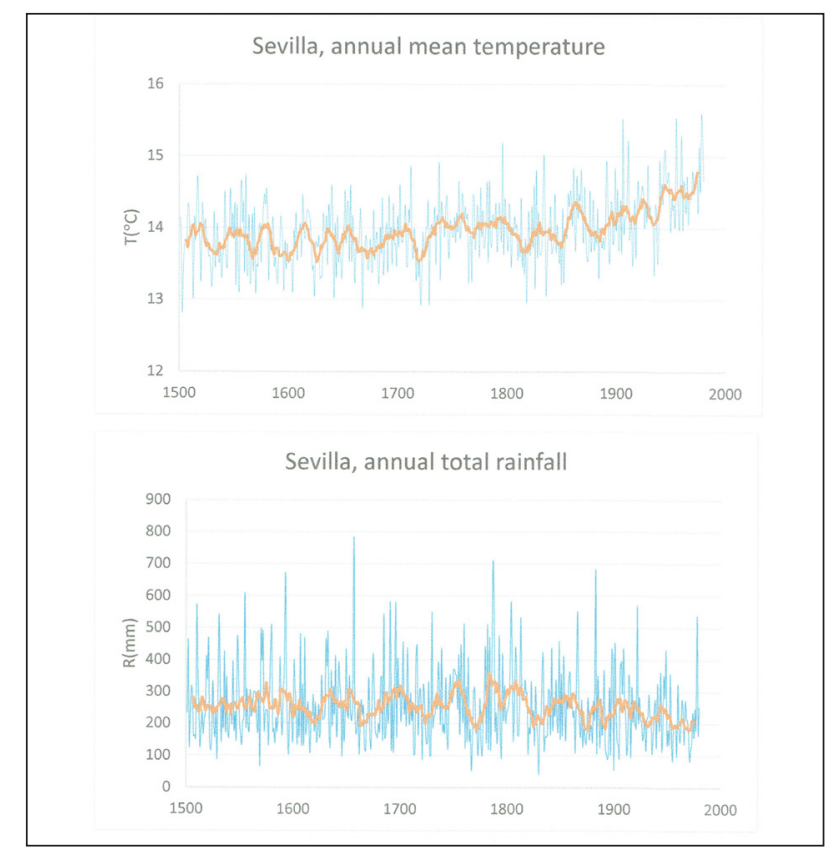

Figure 2. Simulations of the MM5 regional climate model for annual mean temperature (top) and cumulated rainfall (bottom) in Sevilla. Thick line: 11 year moving averages.

\section{Discussion}

\subsection{General characteristics of the LIA in Andalusia}

Most of the proxy data are directly related to rainfall, but not to temperature. Only in the case of glacial studies in Sierra Nevada, and for short periods with documentary data, it is possible to infer temperature conditions in the past. Nevertheless, inferences obtained from proxy data show a cold period, with values lower than the 20th century mean value: $-0.9^{\circ} \mathrm{C}$ in Sierra Nevada mountains, and $-0.5^{\circ}$ in the Guadalquivir River Basin. Note that these values are very similar to the estimations from climate model simulations (of order of $0.4-0.6^{\circ} \mathrm{C}$ lower than the 20 th century mean value in Seville). Among the main natural forcings of climate change, it has been considered the eruption of several large volcanoes (Crowley, 2000). Although volcanic impacts are restricted to a few years, they may be important in different periods, as for instance at the beginning of the 19th century, when the eruption of Tambora, on the Island of Sumbaya (Indonesia) in April 1815, has been identified as the main driving force for the so-called 'year without a 
summer' 1816 . This year summer temperatures were around $2^{\circ} \mathrm{C}$ cooler than those of the period 1871-1900 (Trigo et al., 2009). In any case, it is necessary to search other proxy data to explore thermal conditions during the LIA in this region.

The comparison between different reconstructions is difficult because of various reasons: all proxies have methodological limitations and uncertainty ranges; there are differences in time resolution; proxies are of local character, and reconstructions may be biased by strictly local events; climate variables represented by proxies may be different (for instance, tree-ring indices inform on spring rainfall, meanwhile lake sediments inform on annual and/or average decadal rains, and paleofloods only on extreme events); in addition, reconstructions are biased by the problem of loss of variance, resulting from a regression-type method (von Storch et al., 2004). Nevertheless, a first approach to this problem may be made. Figure 3 shows the general characteristics (wet or dry) of 30-year periods, obtained from the proxies commented in the previous section. This is a simple approach to the problem, due to the different time resolution and periodization found in the respective analysis. In the case of paleosimulations, the mean value of annual rainfall for each-30 year period (R) was compared to the mean of the complete period 1501$1990\left(R_{r e f}\right)$. If $R>R_{r e f}$ the period was classified as wet (dry if $\left.R<R_{r e f}\right)$. Reconstructions and simulations are both subject to their own strengths and weakeness since they are both affected by different sources of uncertainty. Climate simulations and reconstructions will only be correlated in the aspects that are driven by the forced response to the system, and it is not expected a perfect match between them (Fernández-Donado et al., 2013).

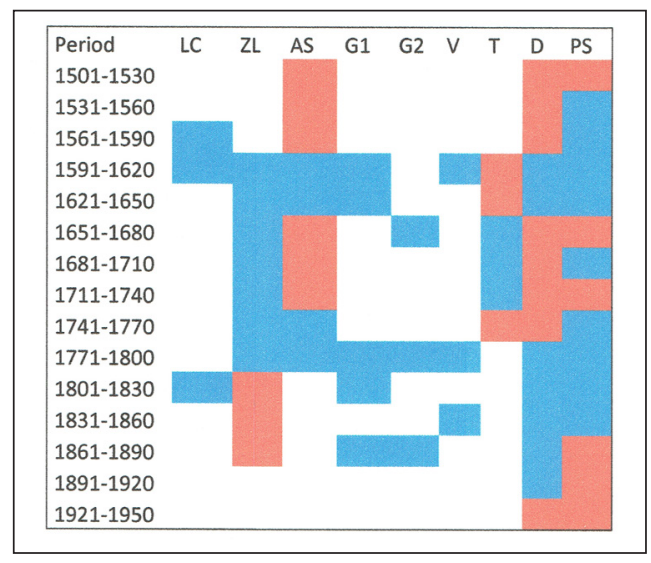

Figure 3. Comparison between results of different proxies (red=dry; blue=wet) for 30-year periods. LC=pollen analysis from La Caldera (Ramos-Román et al., 2016); ZL=Zoñar Lake (Martín-Puertas et al., 2008, 2011); AS=Alborán Sea (Nieto-Moreno et al., 2013); G1=paleofloods from Guadalquivir River (Uribelarrea and Benito, 2008); G2=paleofloods from Guadalentín River (Benito et al., 2010); $V=$ paleofloods Vera river (Schulte, 2002); T=tree-ring (Creus and Saz, 2005); D=documentary data (Rodrigo et al., 2000); PS=paleosimulations (Gómez-Navarro et al., 2011, 2012).

The comparison shows some periods with general wet conditions, like 1591-1650, 1771-1800, and 1801-1860. From a qualitative point of view, most of the studies characterize 
the LIA in Andalusia as a wet period, although with high variability, especially when time resolution is small (seasonal-annual, as in the case of tree-rings). Main discrepancies may due to spatio-temporal differences between proxies. It is notorious the case of tree-rings, opposite to the other proxies, especially during the period 1591-1650. Tree-rings are from Cazorla and Filabres mountains, to the east of the region, and constitute a proxy of spring rainfalls. The other proxies inform on annual and/or decadal averages, in many cases corresponding to the western area of the region, from Guadalquivir River Basin to Sierra Nevada mountains. In this area the main contribution to total annual rainfall occurs in winter (Martín-Vide and Olcina, 2001). Therefore, we must take into account the seasonal and spatial variability in the region to understand these discrepancies.

Air temperature and precipitation are usually connected by several mechanisms related to the correspondence between cloud cover/precipitation, shortwave and longwave radiation balances (Power et al., 1998; Trenberth, 2011; Berg et al., 2015), as well as soil moisture and latent heat flux (Déry and Wood, 2005). Table I shows the correlation coefficients between seasonal mean temperature and cumulated rainfall of five cities in the region, ordered from west to east. Data from ECA\&D database for the period 1951-2016 were used (data and metadata available at http://www.ecad.eu, Klein-Tank et al., 2002). The main results of this analysis are the existence of positive correlations between mean temperature and rainfall in winter in western stations (Huelva and Seville), meanwhile there are not significant relationships in eastern stations (Málaga, Granada, Almería); there is a significant negative relationship in spring for all the stations, and there are not significant relationships in autumn (due to the low magnitude of summer rainfall, results corresponding to summer must be considered cautiously and they will not be commented).

Table 1. Correlation coefficients between seasonal mean temperature and cumulated rainfall of five Andalusian localities from 1951 to 2016 (*: significant at the 95\% confidence level).

\begin{tabular}{|l|c|c|c|c|}
\hline \multicolumn{1}{|c|}{ Station } & Winter & Spring & Summer & Autumn \\
\hline Huelva & $+0.42^{*}$ & $-0.27^{*}$ & -0.17 & -0.01 \\
\hline Sevilla & $+0.43^{*}$ & $-0.38^{*}$ & $-0.41^{*}$ & +0.06 \\
\hline Málaga & +0.15 & $-0.31^{*}$ & $-0.30^{*}$ & -0.04 \\
\hline Granada & -0.05 & $-0.56^{*}$ & $+0.27 *$ & +0.06 \\
\hline Almería & -0.01 & $-0.40^{*}$ & -0.25 & -0.09 \\
\hline
\end{tabular}

In winter western stations are opened to the influence of western/southwestern warm and wet Atlantic flows, favoring a warm-wet mode (Fernández Montes et al., 2012). On the other hand, anomalous cold conditions are usually driven by anticyclonic subsidence, which is responsible of winter frosts in many inland stations (Fernández-Montes and Rodrigo, 2012), and northern/northeastern flows (Rodríguez-Puebla et al., 2010), which provides moderate or under normal precipitation totals, translating into a positive correlation. In eastern stations, predominant western/southwestern circulations usually lead to warm and dry conditions, due to its location in rain-shadow areas (Fohën effect), resulting in negative or non-significant relationships. This result underlines the convenience of distinguishing between western and eastern stations, particularly in winter. 
In spring, radiative heating (cooling) that appears in dry (wet) periods, under anticyclonic (cyclonic) conditions and clear (overcast) skies, as well as soil moisture-atmosphere interaction (Trenberth, 2011), explain the negative correlation coefficients found in the five stations. In autumn, a transition season from warm half-year to winter, the convective activity (which would imply positive correlations mainly in eastern stations) counteracts the other physical mechanisms, and non-significant correlations were obtained.

If these relationships between temperature and rainfall are valid for the past, we can explain past rainfall variability to some degree: low temperatures imply low rainfall in winter (droughts) and high rainfall in spring in western stations, yielding high intra-annual variability in these stations. On the other hand, the negative correlation between temperature and rainfalls in spring explains the predominance of cold-wet conditions found from the analysis of many proxy data. Nevertheless the analysis of the covariability of temperature and rainfall, and therefore, of the alternation of coldwet, cold-dry, warm-dry, and warm-wet periods, is a subject that deserves a more deep research (Fernández-Montes et al., 2017).

The advection of moist air masses from the Atlantic Ocean is directly related to the North Atlantic Oscillation (NAO), especially in winter (Fernández-Montes et al., 2012). The association between fluctuations in the NAO and rainfall regime in the Iberian Peninsula has been studied in many works (Zorita et al., 1992; Goodess and Jones, 2002). There is a strong negative relationship between NAO phases and rainfall in the study region (Pauling et al., 2006): in the positive NAO phase there is an intensification of the high pressure in the western Iberian Peninsula, producing blocking situations over the study area, absence of rainfall and droughts. In contrast, under the negative NAO phase, the Atlantic cyclones are shifted southward, causing intense rainfall and river floods. Luterbacher et al. (2002) noted that seasonal precipitation from Andalusia is a crucial predictor for sea level pressure reconstructions in southwestern Europe. In fact, this relationship was used to reconstruct the winter NAO index back to AD 1501 from documentary data in Andalusia (Rodrigo et al., 2001).

The NAO influence decreases from west to east, because of the presence of mountains, which prevent Atlantic cyclones and their associated fronts to arrive at eastern locations. The percentage of variance of monthly rainfall explained by NAO fluctuations in winter during the instrumental period, from mid-19th century to the end of the 20th century, is around $30 \%$ in western locations, and around 15\% in Almería, to the southeast of the region, where rainfalls depend essentially on the Mediterranean easterly moist flows (Muñoz-Díaz and Rodrigo, 2003). Winter rainfalls in the study area do not vary in a linear way with respect to the phase and intensity of the NAO: the influence of the negative NAO phase is higher for western area than for eastern area; however, the influence of the positive NAO phase is similar for the two areas (Muñoz-Díaz and Rodrigo, 2004). Therefore, it is expected that dry periods be detected in the whole region, meanwhile wet periods show spatial differences, depending on the location of the proxy data. A NAO reconstruction derived from the comparison of Moroccan and Scottish treering data (Trout et al., 2009) shows several multidecadal intervals of strongly negative NAO within the LIA, from AD1550 to mid-19th century. Interdecadal fluctuations in this NAO reconstruction correspond well with the variability reflected by other NAO 
reconstructions (correlation coefficients of order of 0.50 ), which indicate prevailing negative NAO from 1550 to 1700 and from 1750-1800, and prevailing positive NAO at the beginning of the 16th and 18th centuries, around 1850, and at the beginning and last decades of the 20th century (Luterbacher et al., 2002), coinciding roughly with wet and dry periods in the region, respectively. The coldest period within the LIA is the so-called Late Maunder Minimum (AD 1645-1715). This period is well known for its scarcity of sunspots, a direct indication of less intense solar radiation and activity (Eddy, 1976). During this period the NAO often remained in its negative state (Luterbacher et al., 2000). However, the NAO is not the unique large-scale circulation mode affecting the region (Qian et al., 2000). It has been detected the predominance in different periods of different sea level pressure patterns (anomalous advection of moisture from the Atlantic Ocean to the European continent connected to one centre of action west of Ireland, or a blocking pattern over the Baltic Sea and eastern Europe (Pauling et al., 2006)). The influence of these patterns on Andalusian rainfall regime deserves more research.

Interdecadal fluctuations of the NAO may explain similar fluctuations in the behaviour of Andalusian rainfall. As we have seen in the previous section, the LIA in Andalusia is characterized by a great variability. Differences between western and eastern areas are ruled by the diminishing influence of the NAO from west to east, and suggest that a uniform description, common to the whole region, must be considered cautiously.

\subsection{Chronological limits of the LIA in Andalusia}

A proper definition for the extension of the LIA is controversial since temperature and hydrological changes at regional scales were not necessarily synchronous, due to the influence of internal variability (Fernández-Donado et al., 2013). Uncertainty exists about when the LIA began, although many authors suggest that it was around AD 1300 (González-Trueba et al., 2008). The coldest period is considered to be the 17 th century, when a social and economic crisis spread globally (Parker, 2013). The end of the LIA is normally dated in the mid-19th century, at the beginning of the industrial period (Le Roy Ladurie, 2004), although according to dendroclimatological studies (Creus, 2000; Manrique and Fernández-Cancio, 2000; Granados Páez, 2011), the end of the LIA in the Iberian Peninsula can be dated in the 18th century, and Sousa and García-Murillo (2003) indicate a gradual process culminating at the beginning of the 20th century.

It seems convenient to study with some detail the chronological limits of the LIA in the region. With this purpose we have made a simple analysis of the longest record available at highest time resolution, the tree-ring width index of Pinus nigra Arnold subsp salzmanni from the Cazorla mountain range (Jaén province), which at annual resolution covers the period AD 1190-1975 (Creus and Puigdefábregas, 1983). This index is a proxy data basically of spring rainfall, but also offers information on thermal conditions during the warm half-year (see the section 2.4, and Table 1). Figure 4 (top) shows the time series of this index, along with the 11 -year moving averages. It can be seen that, after an initial period with moderate 
values, index values are high from 14 th century to 18 th century, especially during the 16th and 17th centuries (although with fluctuations), and there is a decreasing trend since the 18th century. Figure 4 (bottom) shows the sum of cumulative deviations with respect to the average value of the complete period $S_{t}$. If two subperiods show a significant change of their average values, this is reflected in a change of slope in the curve that represents the cumulative deviations against time. This method was used by Rodrigo et al. (2000) to analyse the alternation of dry and wet periods from documentary data. The result indicates the most notable changes in the slope of the curve in the years 1335 (minimum absolute of $S_{t}$ ), and 1773 (maximum absolute of $\mathrm{S}_{\mathrm{t}}$ ). This result allows to establish the existence of three periods in the time series: the first would correspond to the warm-dry period called Medieval Climate Anomaly; the second one, from 1335 to 1773, corresponds to the LIA, with predominance of wet and cold conditions; and the third one to the ending of the LIA and the global warming characteristic of the 20th century, with a clear decreasing trend of the index.

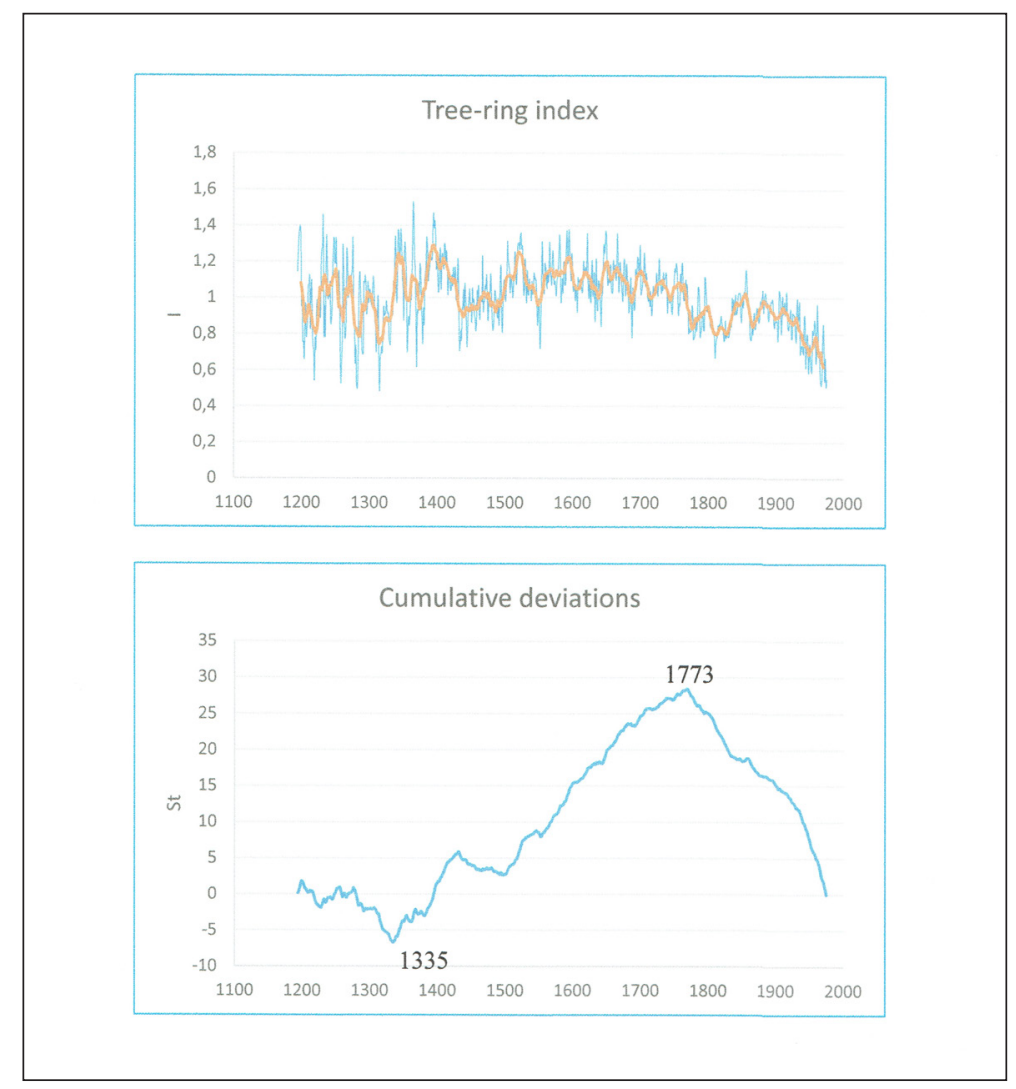

Figure 4. Top: Width tree ring index of Pinus nigra Arnold, Cazorla (data from Creus and Puigdefábregas, 1983). Thick-line: 11-year moving averages. Bottom: Cumulative deviations of the tree ring index, period 1194-1975. Minimum and maximum of the curve are indicated. 
The best reliability test of the results is to see whether there is other evidence (from different sources of data or from other neighbour regions) that show similar characteristics. At this time-resolution documentary data are the best candidate. Unfortunately, the study of historical evidences previous to AD 1500 is a pending issue. Most of manuscripts and chronicles corresponding to the medieval period in Andalusia are written in Arabic. Arabic texts could well represent a useful source for the study of climatic conditions during the Medieval Climate Anomaly, and the transition to the beginning of the LIA (Jones et al., 2009).

Tree-ring index establishes the end of the LIA in the AD 1770s decade. However, cold and wet conditions in Andalusia continued at least until mid-19th century, and especially during the Dalton Minimum period AD 1790-1830 (Rodrigo et al., 2012). This period is characterized by a minimum in solar irradiance (Wagner and Zorita, 2005) and intense volcanic activity, with the Lakagígar eruption in Iceland in 1783 (Brázdil et al., 2010), and Tambora eruption in Indonesia in 1815 (Trigo et al., 2009). Main impacts of these conditions were the frequent rainfalls and floods of the Guadalquivir River in Seville during the 1780s (Domínguez-Castro et al., 2014), and the so-called 'year without summer'1816, with temperature anomalies within the -1.2 and $-2^{\circ} \mathrm{C}$ range (Trigo et al., 2009). These discrepancies may be due to the spatial differences within Andalusia (Cazorla mountains are situated to the east of the region, and documentary data are mainly related to the Guadalquivir River basin). Nevertheless, more research is necessary to analyze this period, particularly from early instrumental data.

\section{Conclusions}

In previous sections we have summarized the results obtained from different proxy data on the LIA in Andalusia. In comparing and discussing results, some questions and research challenges have appeared:

(i) It is necessary to search new data to explore thermal conditions during the LIA in this region.

(ii) Climatic conditions vary from west to east, from predominant Atlantic influence to Mediterranean influence, so an unique regional series may mask spatial differences (on the opposite, the local character of most of the proxy data may be misleading when we try to obtain a general overview of the climatic behaviour of the entire region). Although the NAO influence seems clear, other teleconnection patterns may play an important role.

(iii) It is necessary to explore at this spatial scale the influence of different climate drivers (solar irradiance, volcanic activity, greenhouse gases), as well as the internal variability of the regional climate, including covariability between temperature and rainfall, and possible feedback mechanisms. A work hypothesis is that changes of external forcings along with internal variability determine changes of atmospheric circulation patterns (NAO), and therefore changes of 
temperature and precipitation, leading to different possible conditions (warmwet, cold-dry, warm-dry, cold-wet).

(iv) In relation to the chronological limits of the LIA in Andalusia, slight differences between distinct proxy data suggest the necessity of enlarging the spatiotemporal resolution of proxy data, mainly documentary data from the medieval period and early instrumental data of the first decades of the 19th century.

\section{Acknowledgments}

Data from regional climate model simulations were provided by Drs. Juan José Gómez Navarro and Juan Pedro Montávez Gómez, of the Atmospheric Regional Modelization Research Group, University of Murcia. The author wish to thank the anonymous referees for their useful comments. This work was carried out within the project Variabilidad, tendencias y extremos del clima en la vertiente mediterránea de la Península Ibérica desde el siglo XVI. Análisis mediante información multiproxy e instrumental (CICYT, Referencia CGL2015-69985-R).

\section{References}

Alberola Romá, A. 2014. Los Cambios Climáticos. La Pequeña edad de Hielo en España. Cátedra, Madrid, $341 \mathrm{pp}$.

Anduaga Egaña, A. 2012. Meteorología, ideología y sociedad en la España comtemporánea. Consejo Superior de Investigaciones Científicas, Madrid, $450 \mathrm{pp}$.

Benito, G., Thorndycraft, V.R., Rico, M., Sánchez-Moya, Y., Sopeña, A. 2008. Palaeoflood and foodplain records from Spain: Evidence for long-time climate variability and environmental changes. Geomorphology 101, 68-77. https://doi.org/10.1016/j. geomorph.2008.05.020.

Benito, G., Rico, M., Sánchez-Moya, Y., Sopeña, A., Thorndycraft, V.R., Barriendos, M. 2010. The impact of the late Holocene climatic variability and land use change on the flood hydrology of the Guadalentín River, southeast Spain. Global and Planetary Change 70, 53-63. https://doi.org/10.1016/j.gloplacha.2009.11.007.

Berg, A., Lintner, B.R., Findell, K., Seneviratne, S.I., Van den Hurk, B., Ducharne, A., Chéruy, F., Hagemann. S., Lawrence, D.M., Malyshev, S., Meier, A., Gentine, P. 2015. Interannual coupling between summertime surface temperature and precipitation over land: processes and implications for climate change. Journal of Climate 28, 13081328. https://doi.org/10.1175/jcli-d-14-00324.1.

Brázdil, R., Pfister, C., Wanner, H., von Storch, H., Luterbacher, J. 2005. Historical climatology in Europe - the state of the art. Climatic Change 70 (3), 363-430. http:// dx.doi.org/10.1007/s10584-005-5924-1.

Brázdil, R., Demarée, G.R., Deutsch, M., Garnier, E., Kiss, A., Luterbacher, J., Macdonald, N., Rohr, C., Dobrovolny, P., Kolár, P., Chromá, K. 2010. European floods during the winter 1783/1784: scenarios of an extreme event during the 'Little Ice Age'. Theoretical and Applied Climatology 100, 163-189. https://doi.org/10.1007/s00704009-0170-5.

Creus, J., Puigdefábregas, J. 1983. Climatología histórica y dendrocronología de Pinus nigra Arnold. In: Avances sobre Investigación en Bioclimatología, CSIC, Zaragoza, pp. 121-128. 
Creus, J. 2000. Dendrocronología y dendroclimatología, o cómo los árboles nos cuentan el clima del pasado. In: J.C. García Codrón (Coord.), La Reconstrucción del clima de época preinstrumental, Universidad de Cantabria, Santander, pp. 81-122.

Creus, J., Saz, M.A. 2005. Las precipitaciones de la época cálida en el sur de la provincia de Alicante desde 1550 a 1915. Revista de Historia Moderna 23,35-48. https://doi.org/10.14198/ rhm2005.23.02.

Crowley, T.J. 2000. Causes of climate change over the past 1000 years. Science 289 (5477), 270277. https://doi.org/10.1126/science.289.5477.270.

Déry, S.J., Wood, E.F. 2005. Observed twentieth century land surface air temperature and precipitation covariability. Geophysical Research Letters 32, L21414. https://doi. org/10.129/2005GL024234.

Domínguez-Castro, F., Vaquero, J.M., Rodrigo, F.S., Farrona, M.M., Gallego, M.C., GarcíaHerrera, R., Barriendos, M., Sánchez-Lorenzo, A. 2014. Early Spanish Meteorological records (1780-1850). International Journal of Climatology 34 (3), 593-603. http://doi. org/10.1002/joc.3709.

Eddy, J.A. 1976. The Maunder Minimum. Science 192 (4245), 1189-1201 . https://doi.org/10.1126/ science.192.4245.1189.

Fernández-Donado, L., González-Rouco, J.F., Raible, C.C., Ammann, C.M., Barriopedro, D., García-Bustamante, E., Jungclaus, J.H., Lorenz, S.J., Luterbacher, J., Phipps, S.J., Servonnat, J., Swingedouw, D., Tett, S.F.B., Wagner, S., Yiou, P., Zorita, E. 2013. Largescale temperature response to external forcing in simulations and reconstructions of the last millennium. Climates of the Past 9, 393-421. https://doi.org/10.5194/cp-9-393-2013.

Fernández-Montes, S., Rodrigo, F.S. 2012. Trends in seasonal indices of daily temperature extremes in the Iberian Peninsula, 1929-2005. International Journal of Climatology 32 (15), 2320-2332. https://doi.org/10.1002/joc.3399.

Fernández-Montes, S., Seubert, S., Rodrigo, F.S., Hertig, E. 2012. Wintertime circulation types over the Iberian Peninsula: long-term variability and relationships with weather extremes. Climate Research 53, 205-227. https://doi.org/10.3354/cr01095.

Fernández-Montes, S., Gómez-Navarro, J.J., Rodrigo, F.S., García-Valero, J.A., Montávez, J.P. 2017. Covariability of seasonal temperature and precipitation over the Iberian Peninsula in high-resolution climate simulations (1001-2099). Global and Planetary Change 151, 122 133. http://doi.org/10.1016/j.gloplacha.2016.09.007.

Fletcher, W.J., Zielhofer, C. 2013. Fragility of Western Mediterranean landscapes during Holocene Rapid Climate Changes. Catena 103, 16-29. https://doi.org/10.1016/j.catena.2001.05.001.

Giorgi, F. 2006. Climate change hot-spots. Geophysical Research Letters 33, L08707. http://doi. org/10.1029/2006GL025734.

Gómez-Navarro, J.J., Montávez, J.P., Jerez, S., Jiménez-Guerrero, P., Lorente-Plazas, R., GonzálezRouco, J. F., Zorita, E. 2011. A regional climate simulation over the Iberian Peninsula for the last millennium, Climate of the Past 7, 451-472. https://doi.org/10.5194/cp-7-451-2011.

Gómez-Navarro, J.J., Montávez, J.P., Jiménez-Guerrero, P., Jerez, S., Lorente-Plazas, R., GonzálezRouco, J.F., Zorita, E. 2012. Internal and external variability in regional simulations of the Iberian Peninsula climate over the last millennium, Climate of the Past 8, 25-36. https://doi. org/10.5194/cp-8-25-2012.

Gómez-Ortiz, A., Oliva, M., Palacios, D., Salvador-Franch, F., Vázquez-Selem, L., SalváCatarineu, M., de Andrés, N. 2012a. The deglaciation of Sierra Nevada (Spain), synthesis of the knowledge and new contributions. Cuadernos de Investigación Geográfica, 41 (2), 409-426. http://doi.org/10.18172/cig.2722. 
Gómez-Ortiz, A., Palacios, D., Palade, B., Vázquez-Selem, L., Salvador-Franch, F. 2012b. The deglaciation of the Sierra Nevada (Southern Spain). Geomorphology 159-160, 93-105. https://doi.org/10.1016/j.geomorph.2012.03.008.

González-Rouco, J.F., Zorita, E., 2011. A regional climate simulation over the Iberian Peninsula for the last millennium. Climate of the Past 7, 451-472. https://doi.org/10.5194/cp-7-4512011.

González-Trueba, J.J., Martín Moreno, R., Martínez de Pisón, E., Serrano, E. 2008. 'Little Ice Age' glaciation and current glaciers in the Iberian Peninsula. The Holocene 18 (4), 551-568. https://doi.org/10.1177/0959683608089209.

Goodess, C., Jones, P.D. 2002. Links between circulation and changes in the characteristics of Iberian rainfall. International Journal of Climatology 22 (13), 1593-1615. http://doi. org/10.1002/joc.810.

Granados Páez, D. 2011. Dendroclimatología isotópica en el Sur de la Península Ibérica: Implicaciones paleoclimáticas y paleohidrológicas. Ph. D. Thesis, Universidad de Granada, Granada, 203 pp.

Jones P.D., Bradley, R.S. 1992. Climatic variations over the last 500 years. In: R.S. Bradley, P.D. Jones (Eds.), Climate since A.D. 1500, Routledge, London, pp. 649-665. http://www.geo. umass.edu/faculty/bradley/jones1992b.pdf.

Jones, P.D., Briffa, K.R., Osborn, T.J., Lough, J.M., van Ommen, T.D., Vinther, B.M., Luterbacher, J., Wahl, E.R., Zwiers, F.W., Mann, M.E., Schmidt, G.A., Ammann, C.M., Buckley, B.M., Cobb, K.M., Esper, J., Goosse, H., Graham, N., Jansen, E., Kiefer, T., Kull, C., Küttel, M., Mosley-Thompson, E., Overpeck, J.T., Riedwyl, N., Schulz, M., Tudhope, A.W., Villalba, R., Wanner, H., Wolff, E., Xoplaki, E. 2009. High-resolution palaeoclimatology of the last millennium: a review of current status and future prospects. The Holocene 19 (1), 3-49. https://doi.org/10.1177/0959683608098952.

Klein-Tank, A.M.G, Wijngaard, J.B., Können, G.P., Böhm, R., Demarée, G., Gocheva, A., Mileta, M., Pashiardis, S., Hejkrlik, L., Kern-Hansen, C., Heino, R., Bessemoulin, P., MüllerWestermeier, G., Tzanakou, M., Szalai, S., Pálsdóttir, T., Fitzgerald, D., Rubin, S., Capaldo, M., Maugeri, M., Leitass, A., Bukantis, A., Aberfeld, R., van Engelen, A.F.V., Forland, E., Mietus, M., Coelho, F., Mares, C., Razuvaev, V., Nieplova, E., Cegnar, T., López, J.A., Dahlström, B., Moberg, A., Kirchhofer, W., Ceylan, A., Pachaliuk, O., Alexander, L.V., Petrovic, P. 2002. Daily dataset of 20th-century surface air temperature and precipitation series for the European climate assessment. International Journal of Climatology 22 (12), 1441-1453. https://doi.org/10.1002/joc.773.

Le Roy Ladurie, E. 2004. Histoire humaine et comparée du climat. Canicules et glaciers XIIIèmeXVIIIème siècles, Editions Fayard, París, 740 pp.

Luterbacher, J., Rickli, R., Tinguely, C., Xoplaki, E., Schüpbach, E., Dietrich, D., Hüsler, J., Ambühl, M., Pfister, C., Beeli, P., Dietrich, U., Dannecker, A., Davies, T.D., Jones, P.D., Slonosky, V., Ogilvie, A.E.J., Maheras, P., Kolyva-Machera, F., Martín-Vide, J., Barriendos, M., Alcoforado, M.J., Nunes, M.F., Jonsson, T., Glaser, R., Jacobeit, J., Beck, C., Philipp, A., Beyer, U., Kaas, E., Schmith, T., Bärring, L., Jönsson, P., Rácz, L., Wanner, H. 2000. Monthly mean pressure reconstruction for the Late Maunder Minimum period (AD 16751715). International Journal of Climatology 20 (10), 1049-1066. https://doi.org/10.1002/ joc521.

Luterbacher, J., Xoplaki, E., Dietrich, D., Jones, P.D., Davies, T.D., Portis, D., González-Rouco, J.F., von Storch, H., Gyalistras, D., Casty, C., Wanner, H. 2002. Extending North Atlantic Oscillation reconstructions back to 1500. Atmospheric Science Letters 2 (1-4), 114-124. https://doi.org/10.1006/asle.2001.0044. 
Machado, M.J., Benito, G., Barriendos, M., Rodrigo, F.S. 2011. 500 years of rainfall variability and extreme hydrological events in southeastern Spain drylands. Journal of Arid Environments 75 (12), 1244-1253. https://doi.org/10.1016/j.jaridenv.2011.02.002.

Mann, M.E. 2002. Little Ice Age Vol I. The Earth system: physical and chemical dimensions of global environmental change. In: M. MacCracken, J.S. Perry (Eds.), Encyclopaedia of global environmental change, Wiley \& Sons, Ltd, Oxford, pp. 504-509.

Manrique, E., Fernández-Cancio, A. 2000. Extreme climatic events in dendroclimatic reconstructions from Spain. Climatic Change 44 (1-2), 123-138.

Martín-Puertas, C., Valero-Garcés, B.L., Mata, M.P., González-Samperiz, P., Bao, R., Moreno, A., Stefanova, V. 2008. Arid and humid phases in southern Spain during the last 4000 years: the Zoñar Lake record, Córdoba. The Holocene 18 (6), 907-921. https://doi. org/10.1177/0959683608093533.

Martín-Puertas, C., Jiménez-Espejo, F.J., Martínez-Ruiz, F., Nieto-Moreno, V., Rodrigo, M., Mata, M.P., Valero-Garcés, B.L. 2010. Late Holocene climate variability in the southwestern Mediterranean region: an integrated marine and terrestrial geochemical approach. Climate of the Past 6, 807-816. https://doi.org/10.5194/cp-6-807-2010.

Martín-Puertas, C., Valero-Garcés, B.L., Mata, M.P., Moreno, A., Giralt, S., Martínez-Ruiz, F., Jiménez-Espejo, F.J. 2011. Geochemical processes in a Mediterranean Lake: a high-resolution study of the last 4000 years in Zoñar Lake, southern Spain. Journal of Paleolimnology 46 (3), 405-421. https://doi.org/10.1007/s10933-009-9373-0.

Martín-Vide, J. 2007. Presentación. In: A. Sousa, L. García-Barrón, V. Jurado (Eds.), El cambio climático en Andalucía: evolución y consecuencias medioambientales. Consejería de Medio Ambiente, Junta de Andalucía, Sevilla, pp. 7-11.

Martín-Vide, J., Olcina-Cantos, J. 2001. Climas y tiempos de España. Alianza Editorial, Madrid.

Muñoz-Díaz, D., Rodrigo, F.S. 2003. Effects of the North Atlantic Oscillation on the probability for climatic categories of local monthly rainfall in southern Spain. International Journal of Climatology 23, 381-397. https://doi.org/10.1002/joc.886.

Muñoz-Díaz, D., Rodrigo, F.S. 2004. Impacts of the North Atlantic Oscillation on the probability of dry and wet winters in Spain. Climate Research 27 (1), 33-43. https://doi. org/10.3354/cr027033.

Nieto-Moreno,V., Martinez-Ruiz, F., Giralt, S., Gallego-Torres, D., García-Orellana, J., Masqué, P., Ortega-Huertas, M. 2013. Climate imprints during the 'Medieval Climate Anomaly' and the 'Little Ice Age' in marine records from the Alboran Sea basin. The Holocene 23 (9), 1227-1237. https://doi.org/10.1177/0959683613484613.

Nicault, A., Alleaume, S., Brewer, S., Carrer, M., Nola, P., Guiot, J. 2008. Mediterranean drought fluctuation during the last 500 years based on tree-ring data. Climate Dynamics 31 (2-3), 227-245. https://doi.org/10.1007/s00382-007-0349-3.

Oliva, M., Schulte, L., Gómez-Ortiz, A. 2011. The role of arification in constrainting the elevation range of Holocene solifluction processes and associated landforms in the periglacial belt of the Sierra Nevada (southern Spain). Earth Surface Processes and Landforms 36 (10), 1279-1291. https://doi.org/10.1002/esp.2116.

Oliva, M., Gómez-Ortiz, A. 2012. Late-Holocene environmental dynamics and climate variability in a Mediterranean high mountain environment (Sierra Nevada, Spain) inferred from lake sediments and historical sources. The Holocene 22 (8), 915-927. https://doi.org/10.1177/0959683611434235.

Oliva, M., Gómez-Ortiz, A., Palacios, D., Salvador-Franch, F., Salva-Catarineu, M. 2014. Environmental evolution in Sierra Nevada (South Spain) since the Last Glaciation, 
based on multi-proxy records. Quaternary International 353, 195-209. https://doi. org/10.1016/j.quaint.2014.02.009.

Oliva, M., Serrano, E., Gómez-Ortiz, A., González-Amuchástegui, M.J., Nieuwendam, A., Palacios, D., Pérez-Alberti, A., Pellitero-Ondicol, R., Ruiz-Fernández, J., Valcárcel, M., Vieira, G., Antoniades, D. 2016. Spatial and temporal variability of periglaciation of the Iberian Peninsula. Quaternary Science Reviews 137, 176-199. https://doi.org/10.1016/j. quascirev.2016.02.017.

Parker, G. 2013. Global Crisis: War, climate change and catastrophe in the seventeenth century. Yale University Press, London, 904 pp.

Pauling, A., Luterbacher, J., Casty, C., Wanner, H. 2006. Five hundred years of gridded highresolution precipitation reconstructions over Europe and the connection to large-scale circulation. Climate Dynamics 26 (4), 387-405. https://doi.org/10.1007/s00382-0050090-8.

Power, S., Tsitkin, F., Torok, S., Lavery, B., Dahni, R., McAvaney, B. 1998. Australian temperature, Australian rainfall and the Southern Oscillation, 1910-1992: coherent variability and recent changes. Australian Meteorological Magazine 47 (2), 85-101.

Qian, B., Corte-real, J., Xu, H. 2000. Is the North Atlantic Oscillation the most important atmospheric pattern for precipitation in Europe? Journal of Geophysical Research 105 (D9), 11.901-11.910. http://doi.org/10.1029/2000JD900102.

Ramos-Román, M.J., Jiménez-Moreno, G., Anderson, R.S., García-Alix, A., Toney, J.L., Jiménez-Espejo, F.J., Carrión, J.S. 2016. Centennial-scale vegetation and North Atlantic Oscillation changes during the Late Holocene in the southern Iberia. Quaternary Science Reviews 143, 84-95. https://doi.org/10.1016/j.quascirev.2016.05.007.

Rodrigo, F.S., Esteban-Parra, M.J., Pozo-Vázquez, D., Castro-Díez, Y. 1999. A 500-year precipitation record in southern Spain. International Journal of Climatology 19 (11), 1233-1253. $\quad$ http://doi.org/10.1002/(SICI)1097-0088(199909)19:11<1233::AIDJOC413>3.0.CO;2-L.

Rodrigo, F.S., Esteban-Parra, M.J., Pozo-Vázquez, D., Castro-Díez, Y. 2000. Rainfall variability in southern Spain on decadal to centennial time scales. International Journal of Climatology 20, 721-732. http://doi.org/10.1002/1097-0088(20000615)20:7<721::AIDJOC520>3.0.CO;2-Q.

Rodrigo, F.S., Pozo-Vázquez, D., Esteban-Parra, M.J., Castro-Díez, Y. 2001. A reconstruction of the winter North Atlantic Oscillation index back to A.D. 1501 using documentary data in southern Spain. Journal of Geophysical Research 106 (D14), 14805-14818. https:// doi.org/10.1029/2000JD900728.

Rodrigo, F.S. 2007. El clima de Andalucía a través de los registros históricos. In: A. Sousa, L. García-Barrón, V. Jurado (Eds.), El cambio climático en Andalucía: evolución y consecuencias medioambientales. Consejería de Medio Ambiente, Junta de Andalucía, Sevilla, pp. 25-41. https://www.juntadeandalucia.es/medioambiente/web/Bloques_ Tematicos/Publicaciones_Divulgacion_Y_Noticias/Documentos_Tecnicos/climate_ change/documento_completo.pdf.

Rodrigo, F.S., Barriendos, M. 2008. Reconstruction of seasonal and annual rainfall variability in the Iberian Peninsula (16th-20th centuries) from documentary data. Global and Planetary Change 63 (2-3), 243-257. https://doi.org/10.1016/j,gloplacha.2007.09.004.

Rodrigo, F.S., Gómez-Navarro, J.J., Montávez-Gómez, J.P. 2012. Climate variability in Andalusia (southern Spain) during the period 1701-1850 based on documentary sources: evaluation and comparison with climate model simulations. Climate of the Past 8 (1), 117-133. https://doi.org/10.5194/cp-8-117-2012. 
Rodríguez-Puebla, C., Encinas, A.H., García-Casado, L.A., Nieto, S. 2010. Trends in warm days and cold nights over the Iberian Peninsula: relationships to large-scale variables. Climatic Change 100 (3-4), 667-684. https://doi.org/10.1007/s10584-009-9721-0.

Sánchez Rodrigo, F. 2016. Afecciones meteorológicas: Medicina y Meteorología en Andalucía, 1754-1852. Obradoiro de Historia Moderna 25, 95-113. http://doi.org/10.15304/ ohm.25.2944.

Schulte, L. 2002. Climatic and human influence on river systems and glacier fluctuations in southeast Spain since the Last Glacial Maximum. Quaternary International 93-94, 85-100. https://doi.org/10.1016/S1040-6182(02)00008-3.

Sousa, L., García-Murillo, P. 2003. Changes in the wetlands of Andalusia (Doñana Natural Park, SW Spain) at the end of the Little Ice Age. Climatic Change 58 (1-2), 193-217. https://doi. org/10.1023/A:1023421202961.

Sousa, L., Morales, J., García-Barrón, L., García-Murillo, P. 2013. Changes in the Erica ciliaris Loefl. Ex L. peat bogs of southwestern Europe from the 17th to the 20th centuries AD. The Holocene 23 (2), 255-269. https://doi.org/10.1177/0959683612455545.

Sousa, A., García-Barrón, L., García-Murillo, P., Vetter, M., Morales, J. 2015. The use of changes in small coastal Atlantic brooks in southwestern Europe as indicators of anthropogenic and climatic impacts over the last 400 years. Journal of Paleolimnology 53 (1), 73-88. https://doi. org/10.1007/s10933-014-9809-z.

Sumner, G., Homar, V., Ramis, C. 2001. Precipitation seasonality in eastern and southern coastal Spain. International Journal of Climatology 21 (2), 219-247. https://doi.org/10.1002/joc.600.

Thorndrycraft, V.R., Benito, G. 2006. The Holocene fluvial chronology of Spain: evidence from a newly compiled radiocarbon database. Quaternary Science Reviews 25 (3-4), 223-234. https://doi.org/10.1016/j.quascirev.2005.07.003.

Trenberth, K.E. 2011. Changes in precipitation with climate change. Climate Research 47 (1-2), 123-138. https://doi.org/10.3354/cr00953.

Trigo, R.M., Pozo-Vázquez, D., Osborn, T.J., Castro-Díez, Y., Gámis-Fortis, S., Esteban-Parra, M.J. 2004. North Atlantic Oscillation influence on precipitation, river flow and water resources in the Iberian Peninsula. International Journal of Climatology 24 (8), 925-944. https://doi.org/10.1002/joc.1048.

Trigo, R.M., Vaquero, J.M., Alcoforado, M.J., Barriendos, M., Taborda, J., García-Herrera, R., Luterbacher, J. 2009. Iberia in 1816, the year without summer. International Journal of Climatology 29 (1), 99-115. https://doi.org/10.1002/joc.1693.

Trouet, V., Esper, J., Graham, N.E., Baker, A., Scourse, J.D., Frank, D.C. 2009. Persistent Positive North Atlantic Oscillation mode dominated the Medieval Climate Anomaly. Science 324 (5923), 78-80. https://doi.org/10.1126/science.1166349.

Uribelarrea, D., Benito, G. 2008. Fluvial changes of the Guadalquivir River during the Holocene in Córdoba (Southern Spain). Geomorphology 100, 14-31. https://doi.org/10.1016/j. geomorph.2007.04.037.

Valero-Garcés, B.L., González-Samperiz, P., Navas, A., Machin, J., Mata, P., Delgado-Huertas, A., Bao, R., Moreno, A., Carrión, J.S., Schwalb, A., González-Barrios, A. 2006. Human impact since medieval times and recent ecological restoration in a Mediterranean Lake: the Laguna Zoñar, southern Spain. Journal of Paleolimnology 35 (3), 441-465. https://doi.org/10.1007/ s10933-005-1995-2.

Von Storch, H., Zorita, E., Jones, J.M., Dimitriev, Y., González-Rouco, F., Tett, S.F.B. 2004. Reconstructing past climate from noisy data. Science 306 (5696), 679-682. https://doi. org/10.1126/science.1096109. 
Wagner, S., Zorita, E. 2005. The influence of volcanic, solar, and $\mathrm{CO}_{2}$ forcing on the temperature in the Dalton Minimum (1790-1830): a model study. Climate Dynamics 25 (2-3), 205-218. http://doi.org/10.1007/s00382-005-0029-0.

Wolf, D., Seim, A., Faus, D. 2014. Fluvial system response to external forcing and human impactLate Pleistocene and Holocene fluvial dynamics of the lower Guadalete River in western Andalucia (Spain). Boreas 43 (2), 422-449. https://doi.org/10.1111/bor.12044.

Zorita, E., Kharin, V., von Storch, H. 1992. The atmospheric circulation and sea surface temperature in the North Atlantic area in winter: their interaction and relevance for Iberian precipitation. Journal of Climate 5, 1097-1108. https://doi.org/10.1175/1520-0442(1992)005<1097:TAC ASS $>2.0 . \mathrm{CO} ; 2$. 